\title{
ROMANIAN RELIGION AND CUSTOMS IN THE MIDDLE OF THE 19TH CENTURY IN THE VISION OF FOREIGN TRAVELERS
}

\author{
Prof. PhD. Elena GHEORGHE, \\ Ph.D. at Valahia University, Secondary school"George Emil Palade", \\ ROMANIA, \\ E-mail: elenagheorghe2007@yahoo.com
}

ABSTRACT

The notes of foreign travelers represent a major source of interest for the reconstruction of Romanian society in the middle of the nineteenth century. Although they were not "professional" historians, most often curiosity or diplomatic missions brought them to these lands, their visits led them to numerous political, economic, cultural and psychological observations.Abundance of travelogues and testimonies on the Romanian Lands of this period represents the consequence of the international reactivation of the "oriental problem" and of the intensification of the struggle for emancipation and national liberation of the peoples of the Balkans. of the culture from which they came, foreign travelers projected, consciously or not, their own light on the realities they presented. In no other historical source will we find anything more picturesque and full of life than in the events and descriptions presented by them.

Keywords: Romanian Principalities; foreign travellers; religion; clergy; churches; monasteries; ritual customs;

\section{INTRODUCTION}

Foreigners have always looked at the Carpatho-Danubian-Pontic geographical area with a certain curiosity. According to Western travels, this derives from two reasons: one that in a south-eastern European world, dominated by completely different elements, in which the Slav is highlighted, a different people live by origin and language, and the second - that this people of Latin origin had embraced the Orthodox confession, instead of the Western Catholic one, as was normal ${ }^{1}$. Moreover, in the church and in the royal chancelleries, the Romanian elite used the Slavic language, accepted, since the middle of the ninth century, as a sacred language, along with Greek and Latin. The use of the Slavic language also required the use of the Slavic alphabet, called Cyrillic, instead of Latin, used by all Romanesque peoples, especially those of the Catholic faith.

A few centuries later, when the Latinity, continuity and spiritual unity of the inhabitants of the northern Danube area returned to the discussions of the great European powers against the background of the ideal of national unity of Romanians, travel literature mentions that Wallachian and Moldovans "belong to theOrthodox Romanian people, they

\footnotetext{
${ }^{1}$ The Dominican John, archbishop of Sultanieh, who was sent, in the early fourteenth century, by Timur Lenk on several trips to conclude anti-Ottoman alliances, noted in his memoir to him that "they (ie Romanians) follow the Greeks in their faith, at least that we also have several places of the order of Preachers and Minorities and we have many Germans living in these parts "(Foreign travelers about the Romanian Lands, vol. I., Volume edited by Maria Holban, Scientific Publishing House, Bucharest, 1968, p. 39)
} 
have the same customs and laws, they speak the same language, which is true with a few small and insignificant changes. These differences consist only in certain <vocal> peculiarities and in the way of pronouncing certain terms. A Wallachian always understands a Moldovan, as the roots and grammatical structure of the two <languages $>$ are unique. The Romanian nation is nothing but one of the branches of the Romanian people. The Romanians consider themselves, in one voice, as descendants of the ancient Romans. This, it seems, corresponds to the truth, because the Roman emperors sent here, to populate the area, a lot of people from all classes (...). The lords of Rome transferred to the lands of the Danube huge displaced masses (...) And so the descendants of the Roman exiles, (...) gradually constituted the population of the Danube principalities and finally formed a single people, with a distinct form of leadership. It has retained, both in its customs and in its traditions, some features of its ancestors."2

\section{ROMANIAN RELIGION AND EDUCATION IN THE VISION OF FOREIGN TRAVELERS}

Curious for all foreign travelers of this period is the attitude of Romanians towards religion. From their point of view, this attitude does not contain that feeling of respect, "with which we, the Orthodox, have always become accustomed to think and talk about the high goals of our church, as well as the main dogmas of the holy Orthodox faith." ${ }^{3}$ Joseph Caillat $^{4}$ speaks in his notes about the soul satisfaction of the Romanians acquired when they arrive in front of the icons, making the sign of the cross, kissing them and lighting candles. ${ }^{5}$

The historical reality in the Romanian Lands in the middle of the 19th century presents us with a completely different perspective on education, being known the fact that the reform of this field was vehemently requested in all the Pasoptist revolutionary programs. For example, the "Islaz Proclamation", which became the Constitution of Wallachia under the revolutionary government, decreed "equal, progressive, integral education for all, as far as possible, according to the faculties of each and without any payment", forcing political factors to set "public education establishments" so that "no son of a citizen of those who are 12 years old and many who will be born from now on will remain outside of education, because this is the base for the future of the country and for employment, as well as the true guarantee of the homeland's settlements." ${ }^{6}$

\footnotetext{
2 Piotr Jadovski, in "Foreign travelers about the Romanian Lands in the 19th century", New Series, Vol. VI (1852-1856), Coordinator of the volume Daniela Bușă, Romanian Academy Publishing House, Bucharest, 2010, p. 166 (will quote "Foreign travelers ...") Russian officer traveling through the Romanian Principalities in the conditions of crossing this territory by Russian troops, at the beginning of the Crimean War. In 1853-1854 he served as "stage chief" and military commander of the city of Buzau, a quality that offered him the possibility of direct and longer contact with Romanians, materialized in the elaboration of an interesting account of social and political realities of the time. His work, "Moldova and Wallachia in contemporaneity. From the notes of an officer", was printed in 1856 in St. Petersburg.

${ }^{3}$ Ibidem, p. 167

${ }^{4}$ A French doctor, awarded the Legion of Honor, he stayed in Bucharest between 1845 and 1848, following the recognition of his diploma after a clinical examination held at Colțea Hospital. The accounts of his journey appeared in the publication "L'Union Medicale" in Paris in March-May 1854. The doctor confessed what were the purposes of this trip to a lesser known region of Europe: first to restore health, then his curiosity and desire to enrich his knowledge regarding the various diseases specific to these places.His travels, especially in Wallachia, allowed him a detailed knowledge of various aspects of Romanian civilization.

${ }^{5}$ Joseph Caillat, in "Foreign travellers...”,p. 517

${ }^{6}$ Anghel Manolache, Gheorghe Pârnuță (coordinators), History of education in Romania, vol. II (1821-1918), Didactic and Pedagogical Publishing House, Bucharest, 1993, p.140
} 
Regarding theological education, it was held in Wallachia, in the four seminars (Bucharest, Râmnicu Vâlcea, Buzău and Curtea de Argeș) reopened in 1851. The future priests studied according to an elementary curriculum for grades I and II, reading and the writing, singing, and ordinance of the church, the explanation of the gospel and the Apostle, "the measure of the lands, and the duties of the jurors," the rhetoric, theology, geometry, and "all parts of grammar". ${ }^{7}$ A few years later, in 1858, a new syllabus was developed in which, in addition to theological knowledge - church history, "moral theology, pastoral and dogmatic theology, church songs", authorities provided it with grammar, arithmetic, principles of geometry, geography of Europe, the history of the homeland, the physicalnatural sciences ". 8 The seminar in Socola with seven years of study continues its activity in Moldavia. In the lower course, for four years, in addition to theological knowledge, lessons in grammar, geography and the history of the homeland, the Russian language and the Greek language are taught. The curriculum of the upper classes also provided for moral theology, canon law, logic, psychology, philosophy, Latin and French. ${ }^{9}$

In 1851, the "Legislation for the organization of church teachings in Moldavia" was issued, through which religious education was organized on three levels: the two-year church schools -in Roman and Huși-, the first section of the Seminary, lasting four years, for the lower clergy and the second section of the seminary, every four years, for the high clergy. Priests were to be made only of those with theological studies, but graduates of four years of study could also become priests. At Socola, 100 students were to be received, of which 25 in the upper course, and at Huși 40 and Roman 70, all boarders. The ambitions of the law were to transform the Socola Seminary into a university-level school. ${ }^{10}$

In Transylvania, on November 1, 1849, the Seminary of Sibiu was reopened, with one year of study, furthermore, starting with 1852/1853, it turned into a two-year course. In the first year, grammar, church history, pedagogy, popular physics and rural economics were taught. For the second year of study the curriculum provided exegetics, the general part of theology, morals, "pastoral and the elaboration of church language, the interpretation of the Gospel"; from the school year 1853/1854 new disciplines were added - arithmetic, geography, canon law, rhetoric and the polemic. ${ }^{11}$ In 1852, the Theological Institute of Arad and the Seminary of Blaj were reopened. The quality of education of the rural population was proportional to that of the priests because they were entrusted with the education of children. Some knowledge of writing, reading and counting was taught to them, in the good old days, in the cemetery, in the shade of the acacias, where "the little ones, often halfnaked, lie on the graves, in the middle of the <orthodox> Greek rite crosses, strangely painted, while an old priest, who is made to look like all the teachers in all the countries, falls asleep under the shade of the moving branches." 12

The same hastily conceived travel descriptions, with disparate information, containing superficial impressions can be found regarding the Romanian secular education from the middle of the 19th century. "The establishment for the reorganization of public education in

\footnotetext{
${ }^{7}$ Ibidem, p. 179

${ }^{8}$ Idem

${ }^{9}$ Ibidem, p. 179

${ }^{10}$ Dragoș Bahrim, Adrian Timofti, "Veniamin Costachi" Seminary (1803-1848), Iași, 2003, p.36

${ }^{11}$ Anghel Manolache, Gheorghe Pârnuță, op. cit., p. 180-181

${ }^{12}$ Charles Doussault, in "Foreign travellers...", p.147-148
} 
the Principality of Moldavia" issued in 1851, stated that "public education is free and open to all Romanians" and provided three categories of schools: primary, secondary and higher. ${ }^{13}$

As primary schools, organized for a period of four years, were considered to be girls' and trades or military schools in the barracks. Girls' schools were to be established in all the residences of the lands, according to a syllabus that included a specific program for primary schools (religion, reading, writing, the four arithmetic operations, practical compositions, practical knowledge of agriculture, measuring the land and the barrels) at which a foreign language was added (for the Central School from Iași), elements of physics, morals, vocal music, hand-work, "drawing flowers and persays", "keeping household expenses calculations", and their duration was of five years. ${ }^{14}$

Secondary education included technical schools, agricultural school ${ }^{15}$ and middle schools. Higher education, lasting three years, was taught in the Academy of Iasi, consisting of the philosophical faculty (with the department of philosophical sciences, mathematical and physical sciences), law, theological sciences, the school of midwives and that of surgery. ${ }^{16}$

The1850 "settlement" in Wallachia, after establishing that education is a "necessary requisite", established the following cycles of education: primary school, beginner, in all county residences, lasting four years, college classes - lasting six years and special (higher) teachings. The "faculty of law" was established, the faculty of exact sciences was divided into three sections: for surveyors, bridge and road engineers and architects, there was also a school of agriculture and home economics. ${ }^{17}$

In Brașov, on September 1, 1850, the Central Orthodox School was opened, ${ }^{18}$ which had "four classes for boys and two classes for girls." The 4th grade of the boys' school was organized so as to be considered as a preparatory class for the gymnasium. In this class the following matters were studied: Religion, Latin, Romanian, German, Geography, arithmetic and natural history (zoology and botany).

\section{HABITS AND SUPERSTITIONS IN THE NOTES OF FOREIGN TRAVELERS}

The lack of education was compensated by taking refuge in faith and superstition. The possibilities to attend a school were minimal, the children received at home an education that determined them to be deeply attached to the Christian faith and the church, but also to a lot of superstitions related to daily life.

Foreigners who knew Romanians saw this combination of a deep faith, despite a lack of theological knowledge, and a belief in supernatural forces. Most of the Catholic religion practitioners believed that prayers were hampered by the multitude of superstitions, the religious practice being degrading and with the possibility of turning man into a voluntary slave. Although the people believed in all sorts of witches, spirits and phantoms, the days of fasting and celebration, so numerous in the Orthodox calendar, are strictly observed. Fasting

\footnotetext{
13 Anghel Manolache, Gheorghe Pârnuță, op. cit., p.148

${ }^{14}$ Ibidem, p. $149-150$

${ }^{15}$ It lasted three years, during which time they studied: rural economics, botany, forest cultivation, rational cultivation of vineyards, improvement of cattle varieties; those who had completed rural economics courses in the technicall schools were also received.

${ }^{16}$ Anghel Manolache, Gheorghe Pârnuță, op. cit. p. 150

${ }^{17}$ Ibidem, p. 151

${ }^{18}$ Cristina Tănase, Aspects regarding the support activity of the Romanian Greek Orthodox central schools from Brașov (1850-1870), in "Țara Bârsei”, new series, no. 11, 2012, pp. 80-92
} 
lasted for several weeks, during which any animal food was forbidden, and only oil was allowed as fat.

It was also believed that holy water works wonders. It was used as an antidote against witchcraft, plague, and any disease to which man is subjected; at the same time he defended the cattle from the thunder and lightning field, the pest trees, the house of fire and the sinking ship. ${ }^{19}$

The sanctification of the water was done after a ceremonial established for centuries, as noted by the French E.N. Flenoque-Melville who transited the territory of the Romanian Principalities during the Crimean War. In the first days of January, he attended the baptism in the water of the river Dâmbovița, at,,Boboteaza” and was amazed by the crowd of participants, getting to ask rhetorically if indeed Romanians are very faithful or just curious by nature: the service lasted two hours, while about 3,000 people, clergy, military and civilian authorities waited in the snow for the end of the ceremony to throw a cross into the river; immediately men and women jumped into the water to retrieve the cross. ${ }^{20}$

Equally curious for foreigners was the habit of Romanians to worship relics. The Austrian Colonel Moritz von Angelli, who was in Iași during the Austrian occupation of the Danube Principalities, is "impressed" by the honor of a saint whose remains dressed in proud robes were placed on a catafalque almost a meter high under the portico. A crowd of believers from all walks of life, from the great nobility to the ragged vagabonds, crowded and pushed around them all day. After short prayers, everyone had to crawl under the coffin and then kiss the saint's forehead, from which he could see through the gold-embroidered clothing a piece of the forehead bone, about the size of a plate." 21

Not a few in the literature of foreign travelers are the stories about the customs related to the main moments in the life of Romanians: birth, marriage or burial.

Between 1851 and 1854, Siegfried Kapper, a Serbian doctor, traveled through Banat and had the opportunity to attend a Romanian wedding in Oravița. The joy and happiness of the bride and groom attributed to the lack of culture was contagious, so that our traveler got out of the carriage and followed the procession of hussars and horsemen, gypsy musicians, the knight and bridesmaid, the groom, the bride and many women; the men, led by the elders, were already gathered at the church. Here the music stopped and "the bride and groom lined up in a semicircle around a round table, covered with a rug, which was placed in the middle of the church, in front of the iconostasis and which was to serve as an altar for the wedding. A simple ebony cross and on each side of it two beautiful flower pots and two beautifully decorated candles with roses formed the entire altar. In front of the cross was a widely used Gospel and on each side of it two paired, thin crowns, in which were woven redgreen ribbons, two equally decorated rings. Immediately after entering the <church>, the bride and groom, who, it is said, were not too close in age, went to the iconostasis to begin their prayer (...) After the prayers, the father, as the Romanians call their priests, came out from behind the iconostasis and gave a candle to each of the two bridegrooms, after which he led them around the table. Here, the bride and groom gave candles to the godparents. The father said a long prayer, tied both hands of the bride and groom tightly to each other with a white towel, said another prayer, and then stepped forward to another parent, folded a piece of cloth, which the groom gives to the bride and wrapped them, on the ends of the newly crowned pair, so that they are now bound to each other with body and soul <and>

\footnotetext{
${ }^{19}$ Edmund Spencer, in "Foreign travellers...",p. 430

${ }^{20}$ E.N.Flenoque-Melville, in "Foreign travellers...",p. 238

${ }^{21}$ Moritz von Angelli, in "Foreign travellers...",p. 561
} 
inseparable. At this point, the blessing parent places one of the wreaths on their clothcovered head, and now the couple finds themselves in a respectful situation where they must $<$ hear > a long line of prayers and songs about them. After being blessed, the pirostries were removed, as well as the wrapped cloth and the handcuffs, and the young man was allowed to kiss his elderly wife to start a sweaty life." ${ }^{22}$

The village elders rewarded the priests' hard work with money. Joseph Caillat gives as a concrete example the case of a lady who, wanting a carefree future, divorces for medical reasons when the Russians enter the country; she marries a Russian officer in the occupation army, but leaves him when his regiment leaves the Principalities. ${ }^{23}$

Immediately after death, the body is washed, shaved and wrapped in a shroud for the grave, in depending on how expensive the family can afford it; his legs are directed towards the door, and usually a coin is hidden in his hand or mouth for the dead to pay for their passage into the other world.

The American doctor James Oscar Noyes met a funeral procession in a village near Bucharest: "The rudimentary coffin was supported by half a dozen villagers (...). Before the coffin walked a person with a basket with cookies eaten in honor of the dead ancestors. He also wore a small Arminden pillar decorated with tassel braids like the ones the country bride adorns herself with on her wedding day. Behind the coffin were two village priests, parents and friends, each carrying a candle and then a number of mourners, pale and with their eyes in the back of their heads, hired for the occasion. Finally, they plucked their hair and screamed loudly as if the peace of the deceased depended on their efforts (...) the procession stopped several times before reaching the village church.

Those who carried the coffin left their burden on the ground. Close relatives and mourners gathered around the coffin and addressed the tenderest words to the dead, hugged him and apologized for the slightest insults they had caused him during his life, proving, at the same time, the pain through funeral chants of glory and regret, moans and the tearing of clothes in a terrifying way (...) Leaving the church, the body was taken to a shallow grave in the courtyard of the place called the Garden of the Dead. . After the priest said the last prayer, the dead and the living were sprinkled with holy water. The coffin was lowered into the grave and a coarse wooden cross was left to mark the resting place of the young Romanian." 24

On the anniversary of the deceased, there is a custom for the family to distribute money and clothes to the poor, as well as unleavened rolls made of flour, sugar, honey, nuts and cheese; vessels full of water and sometimes food are placed along the way for travelers.

In Moldova, in the case of those with a certain amount of welfare, the notes speak of the luxury of burials. Here the priests came from all areas to the vigil, depending on the rank and wealth of the deceased. Each priest received a certain amount of money and a wax candle with towels, which he carried in his hand during the service. Also, at the end of the ceremony, the last cookies, cakes, wine and brandy also belonged to the priests. ${ }^{25}$

The village world, the life with the rhythm kept for hundreds of generations, reveals to foreign travelersa true popular calendar in which every day contains an essence. Every day has a story, a piece of advice, a lesson.

\footnotetext{
${ }^{22}$ Siegfried Kapper, in "Foreign travellers...",p. 112-114

${ }^{23}$ Joseph Caillat, in "Foreign travellers...",p. 517

${ }^{24}$ James Oscar Noyes, in "Foreign travellers...",p. 216-217

${ }^{25}$ Moritz von Angelli, in "Foreign travellers...",p. 561
} 
The days of the Romanians were divided into splendor and misfortune. In fact, every day has its special activity that could not be left to another time. For example, the Romanians wash on Wednesday and spin on Saturday. Tuesday is the worst of all days of the week. On that day, women rarely wash and comb their hair; no journey is begun and no important activity is undertaken. No peasant woman will take the needle in her hand on Tuesday, for fear that the Savior would feel every sting and thus be crucified again. On certain days of the year they they refrain from cutting anything with scissors so that the wolves do not harm the sheep, only the tailors believe that they self-absolve from this tradition. Panicked by the disastrous effects of the frequent epidemics, women in rural areas imagine that they can prevent the plague by burning a shirt that has been spun, woven, and made in less than twenty-four hours. When it starts to thunder and lightning, the superstitious Romanian makes the sign of the cross and falls to the ground.

Speaking of the population, as a number of inhabitants in the middle of the 19th century, it is interesting the note of doctor Caillat who establishes for Wallachia, without including Bucharest, a population of $2,000,000^{26}$ inhabitants. The total population of the Principalities in 1854 was considered to be 4,000,000 inhabitants, and in 1859 4,424,961 inhabitants. $^{27}$ American physician James Oscar Noyes identified, at the same time, a population of 4,000,000 souls, of which 2,500,000 belonged to Wallachia and the rest to Moldova. Very important for our national history is his observation that "Romanians are not limited, however, to the principality, but are spread throughout Transylvania, Bessarabia and Bukovina, numbering more than 7,000,000 people." 28

A picture of the births in Moldavia in 1840 could look like this: Orthodox 21,867 of which 11,796 boys and 10,071 girls, Catholics 1838 of whom 963 boys and 875 girls; to these are added 1,011 Jews (571 boys and 440 girls) and 155 Armenians (78 boys and 77 girls). ${ }^{29}$ In 1842 , Thibault Lefebvre ${ }^{30}$ counted 6,900 clerical families in Wallachia,4,800 families of deacons, 3,200 families of teachers and 4,500 monks and nuns. ${ }^{31}$

\section{ROMANIAN CHURCHES AND MONASTERIES IN THE LOGS OF FOREIGN TRAVELERS}

Travelers who passed through the North-Danube area in the middle of the 19th century also give interesting news about the Romanian church, respectively about its hierarchical organization. For example, the Frenchman Eugene Poujad ${ }^{32}$ says that Wallachia has a metropolis and three belonging bishoprics, with an annual income of 3 million piastres (almost 1,148,000 francs), and Moldova has a metropolis and two belonging bishoprics, with

\footnotetext{
${ }^{26}$ Joseph Caillat, in "Foreign travellers...",p. 531

${ }^{27}$ C.I.Istrati, A page from the contemporary history of Romania from the medical, economic and national point of view, Alesandru A Grecescu Printing House, Bucharest, 1880, p. 60

${ }^{28}$ James Oscar Noyes, in "Foreign travellers...",p. 216

${ }^{29}$ Joseph Caillat, in "Foreign travellers...", p. 532

${ }^{30}$ Lawyer at the Court of Cassation and the Council of State, member of the Blois Academy, the Berry Society and the Paris Political Economy Society, one of the French travelers who left precious testimonies about the economic state of the Romanian space. He visited Wallachia in 1853 and 1858.

${ }^{31}$ Thibault Lefebvre, in "Foreign travellers...",p. 247

${ }^{32}$ Eugene Poujad, French consul in Bucharest between 1849-1854, a remarkable connoisseur of Eastern problems, represented the tendency of the Western power to approach our countries. He married, in 1850, a Romanian woman, Maria, the daughter of the great ban Costache Ghica. He became a fighter for the defense of the Romanians' rights. A convinced unionist, he proposed since 1849 the achievement of the union of the Principalities.
} 
an annual income of millions of francs $(3,976,000$ francs). Their income was fixed by the Organic Regulations, as follows: in Wallachia, one-fifth of this income is made available to the holders for alms, personal expenses and their homes; the remaining four-fifths are used for the maintenance of churches, the payment of ecclesiastical courts, the treatment of priests and vicars, seminar fees and religious instruction, and one-tenth of the total amount is considered necessary as a reserve for unforeseen expenses. In Moldova, income is divided as follows: 900,000 piastres for church maintenance, food and housing for their servants; $1,800,000$ piastres belong to the state and are intended for charities and public education; more than half of the amount is considered to be kept as a reserve. ${ }^{33}$

The large number of churches and monasteries impressed foreigners. The French traveler Adolphe Joanne wrote in 1846 that in the city of Bucharest there could be "10050 houses, 20 hotels, 26 monasteries, 130 Orthodox churches, a Catholic church, an Armenian church, a Reformed church, 5 synagogues, 10 inns, a seminary, a college, 3 boarding houses, 80 schools, 4 printing houses, 1775 horse crews, 7502 carts, 18,930 horses, 70 barges, a foreign theater". 34

Charles Doussault believes that St. George's Church is one of the most important in Bucharest and regrets a failed restoration: "Once decorated on the outside with paintings and arabesques, St. George's Church suffered the mutilation of the hope with which German architects are so generous to these unusual monuments. The railing of the church porch, in Byzantine style, full of elegance and originality, still allows us to guess the picturesque appearance that the decoration could produce on the azure sky, often splendid, in these warm lands, now covered with this destructive linen of lime spoilage ",35. The interior of the churches has a structure similar to that of the Catholic churches, with the difference that in our country "the walls are equipped with benches (...) on which one sits during the service" ${ }^{\text {36. }}$.

In 1854, three monasteries are mentioned near the mountainous area of Buzău: Ciolanu, Valea Mărului and Vintilă Vodă. The traveler is impressed by the beauty of the landscape, especially since the Ciolanu monastery was quite difficult to reach on horseback, so the trip was made on foot. For a start, you enter the first courtyard of the monastery where there is a small building, to receive and host the faithful who came to visit the monastery; then came some warehouses and the monastery kitchen. "The buildings were built of mountain stone and partly of boulders in the river. In the second courtyard were two churches: one with the name of Jesus the Savior, the second with the patron saint of the Holy Trinity. The founder's cells are united with the interior of the patron saint of the Holy Trinity, and the monks' cells begin on the other side of the church and go under the mountain amphitheater. A few trees grow near each cell, and their green crown does not allow the hot glow of the sun to pass through, providing their occupants with a pleasant coolness. From the windows of the cells the view to the surrounding mountains is particularly beautiful. " Eight monks and the abbot, almost 70 years old, lived here. He was a wise man of Serbian origin, speaking Russian like our traveler, which gave the visit a relaxed and pleasant atmosphere. In this context, two very valuable cult objects are revealed that did not adorn the monastery for fear of a possible robbery of the Turks: a cross sent to the monastery by the

\footnotetext{
${ }^{33}$ Eugene Poujad, in "Foreign travellers ..." p. 495

${ }^{34}$ Simona Vărzaru, Through the Romanian Countries. Foreign travelers from the 19th century, Sport-Turism Publishing House, Bucharest, 1984 p. 114

${ }^{35}$ Charles Doussault, in "Foreign travellers...", p.151

${ }^{36}$ Piotr Jadovski, in "Foreign travellers...",p.171
} 
voivode Mihai Viteazul, as a sign of gratitude after the victory over the Turks and a small Slavonic gospel, plated with silver decorations, about which it is not known how it came into possession of the monastery. ${ }^{37}$

Regarding such robberies, Edmund Spencer has the same perplexity, who, being aware of the fact that "the richest monasteries can be found in Moldova and Wallachia" wondered in his memoirs "how they escaped when the country was deserted and robbed, so often, by the armies of Russia and Turkey ". ${ }^{38}$ Continuing the series of monasteries in Wallachia, Eugene Poujad successively recalls "Tismana, located in a picturesque pass on a small river with this name; Arnota, founded by an Albanian prince and which served as a refuge for the inhabitants during the Tatar invasions; Polovragi, built on the same track of Olteț, where this river escapes from a deep cave, rich in stalactites; Cozia, built in front of Olt, where this untamed river escapes from the Carpathians to bathe Wallachia; Horezu, the most important of the five monasteries built by Brâncoveni, one of the richest in the whole of Wallachia and whose abbot still has the right to be named by the old princess Brâncoveanu, retired to Văratic." 39 Impressed was the traveler from the convent of nuns from Ostrov where "every nun has her house under thick secular trees, which hide her from view. A small arm of the Olt, which flows quietly, separates the island from the road and a wide boat leads the passengers here, which is announced by the sound of a bell. The abbess of Ostrov only wears church clothes when she has foreign visitors. She is usually dressed in the latest fashion from Paris and receives her toilets from Bucharest." 40

For Moldova, the monasteries from Neamț, Agapia and Văratic are the most frequently mentioned in the travel diaries of foreign travelers.

In Văratic, the older and more devoted nuns lived "in the shadow of the sanctuary. But as each of the nuns has her own house, separated from the others by a garden or trees, the youngest and most fashionable scatter here and there, at the foot of the hills, secluded houses, resembling an English village rather than a cell. Their rules are not very strict, judging by the details: they are said to have the right to offer hospitality to their visitors, but not more than three days. (...) At Agapia, the valley is very narrow, the monastery very isolated, the rules are strict. "41

\section{CONCLUSION}

The interest that the accounts of travelers and consuls show for the reconstruction of life in the Principalities is obvious. In most of them, the mentality, education, daily life, Romanian cities and villages from the first half of the 19th century are described as inferior to the settlements in Western Europe. However, the fact that the territory of the Romanian Principalities was often the theater of the Russian-Turkish and Russian-Austro-Turkish wars must also be taken into account. The travelers registered the consequences of those scourges, which delayed the development process of the Romanian society.

Foreign travelers, coming from noble or bourgeois backgrounds, were critical of Romanian customs and mentalities, considering them much too influenced by the oriental spirit. Forcing the note of interpretations a little, we can say that Saint-Marc Girardin

\footnotetext{
${ }^{37}$ Ibidem, p.191-192

${ }^{38}$ Edmund Spencer, in "Foreign travellers...",p. 429

${ }^{39}$ Eugene Poujad, in "Foreign travellers...",p. 494

${ }^{40}$ Ibidem, p.495

${ }^{41}$ Edouard Grenier, in "Foreign travellers...”,p. 672
} 
observes, as early as 1836, what Maiorescu would later call "bottomless forms": taken from Western civilization rather its external aspects ".42

Springed from experience and wisdom of life, from joy or pain, the elements of culture and popular traditions transmitted values and created bridges between generations. Religion, traditions and customs are priceless treasures, which define a people, making it unique, steadfast and immortal; Romania is known for its popular customs, some as if taken from fairy tales. Despite globalization, they have been preserved and passed down from generation to generation.

${ }^{42}$ Simona Vărzaru, op.cit., p.60 


\section{BIBLIOGRAPHY:}

[1] ${ }^{\text {***k }}$ Foreign travelers about the Romanian Lands, vol. I., Volume edited by Maria Holban, Scientific Publishing House, Bucharest, 1968

[2] ${ }^{* * *}$ Foreign travelers about the Romanian Lands in the 19th century, New Series, Vol. VI (1852-1856), Coordinator of the volume Daniela Bușă, Romanian Academy Publishing House, Bucharest, 2010

[3] Bahrim, Dragoș, Timofti, Adrian, "Veniamin Costachi" Seminar (1803-1848), Iași, 2003

[4] Istrati, C., I., A page from the contemporary history of Romania from the medical, economic and national point of view, Alesandru A. Grecescu Printing House, Bucharest, 1880

[5] Manolache, Anghel, Pârnuță, Gheorghe (coordinators), History of education in Romania, vol. II (1821-1918), Didactic and Pedagogical Publishing House, Bucharest, 1993

[6] Stroia, Marian, Aspects of the Romanian society in the vision of foreign travelers (1774-1821), in "Revista de Istorie", 38, 1985, 5, pp. 448-455

[7] Tănase, Cristina, Aspects regarding the support activity of the Romanian Greek Orthodox central schools from Brașov (1850-1870), in "Țara Bârsei”, new series, no. 11, 2012, pp. 80-92

[8] Vărzaru, Simona, Through the Romanian Countries. Foreign travelers from the 19th century, SportTurism Publishing House, Bucharest, 1984 